\title{
Assessment of Student Welfare Programs in the State Universities and Colleges of Samar Island
}

\author{
Ronaldo A. Amit \\ University of Eastern Philippines, Catarman, Northern Samar, Philippines
}

\begin{abstract}
How to cite this paper: Ronaldo A. Amit "Assessment of Student Welfare Programs in the State Universities and Colleges of Samar Island" Published in International Journal of Trend in Scientific Research and Development (ijtsrd), ISSN: 24566470, Volume-3 | Issue-3 , April 2019, pp.832-836, URL: https://www.ijtsrd.c om/papers/ijtsrd23 175.pdf

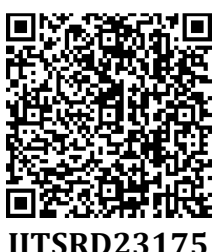

Copyright (C) 2019 by author(s) and International Journal of Trend in Scientific Research and Development Journal. This is an Open Access article distributed under the terms of the Creative Commons

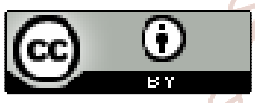
Attribution License (CC BY 4.0) (http://creativecommons.org/licenses/ by/4.0)

\section{INTRODUCTION}

Student welfare program and services are basic services and programs needed to ensure and promote student well-being (CHED Memo 2013). The programs and services rendered to the students by the Student Affairs Office are as follows: Admissions Services, Career and Placement Services, Economic Enterprise Development, Food Services, Guidance and Counseling Services, Health Services, Information and Orientation Services, International Student Services, Research, Monitoring and Evaluation of Student Affairs and Services, Safety and Security, Scholarship and Financial Assistance, Services of Students with Special Needs, Student Discipline, Student Handbook Development, and Student Housing.

The school administration has the responsibility to provide the best learning environment to students. To make this possible, there is a need for an efficient and effective delivery of student services. Administrators are concerns that by delivering effective student services, state colleges, and universities need the call of the national government in its effort to develop the country as a whole (Ludeman, 2002).

Student affairs and services must be delivered in a manner that is seamless, meaningful, and integrated with the academic mission of the institution. These practices and resulting policies must be built upon sound principles and research, and carried out by partnering with the entire campus community.

The concept of a student services or student affairs profession is a relatively new phenomenon. Until the early part of the 19th century, the teaching faculty and a few clerical assistants handled the few non-instructional functions for students, e.g., accommodations, food service, student discipline and advising, and some activities. The colonial model of higher education did not focus on the whole student and access to an education was limited to those who could afford it.

Soon, however, the types and number of students coming to higher education began to swell (many of them women who were being admitted to higher education for the first time in several centuries). Academics, who were previously handling these functions, even though they knew next to nothing about administering such initiatives and counseling students, began calling for more assistance in carrying out these non-instructional duties. In the United States, Deans of Women, Dean of Men, and Deans of Students began to be appointed because of the increases in numbers and types of students who were enrolling in higher education. Also during the late 19th century, the teacher/scholar and 
research models were being adopted all over the world, moving away from the main purpose being teaching and service. Governments and communities were turning to higher education systems to generate research and development for the military, industry, health and other social programs (Ludeman, 2002).

Thus, came the birth of a new profession: student affairs and services. These staff members were now in charge of not only housing and feeding students, but also physical and mental health care became a necessity on many college campuses. Recreation, cultural activities, sports, testing, orientation, career assistance, job placement, financial assistance, and disability services all became new units in many countries. They were initiated to help meet emerging student types and their corresponding student needs. Unfortunately, the concept of integration of student services and programs with the instructional activities of the faculty was not considered. This move toward specialization of instructional and non-instructional functions continued to have a negative impact on faculty/staff working relationships and, more importantly, on resultant learning outcomes for students until the 1990s.

Following World War II, campuses everywhere continued to become more diverse because returning war veterans were accessing higher education through the use of government benefits designed for that purpose. During the last quarter of the 20th century, the variety of students coming to higher education continued to expand all around the world. Joining the traditional, well-to-do men were women students, students of color, older non-traditional students, single parents, students with disabilities, and others as well. As a result, new professionals were hired to work with these new groups to meet their needs and help them to become successful students (Ludeman, 2002).

During the 1990s, the focus of student affairs and services moved toward an enhancement of student learning outcomes and working hand-in-hand with the teaching faculty and others on campus with those ends in mind. This development has given new hope to the idea that an integrated campus effort will produce better results for students and more efficient use of resources for all campus units.

The degree to which the wide array of student services and programs is developed in a particular country depends on the demands for and access to higher education, the cultural context, and the ability of the infrastructure to provide this level of student support. Each part of the world, and in many cases each country, must review its commitment to higher education and include in the financial infrastructure some major provision for the necessary student affairs and services functions to make sure student needs are being met. In addition, various student activities should be developed so that they blend well with the instructional nature of the institution and, therefore, enhance the desired student learning outcomes. Higher retention and graduation rates will be the results, justifying the commitment and the resources provided up front (Ludeman, 2002).

Fronda (2000), in one of her speeches, stated that student affairs programs and services are increasingly expanding from traditional roles to more focused efforts of helping the students maximize learning outcomes. She also identified that the measures and areas of concern of the Office of Student Affairs and Services include admission, student orientation, scholarship financial grants, career orientation, and testing and assessment.

\section{METHODOLOGY}

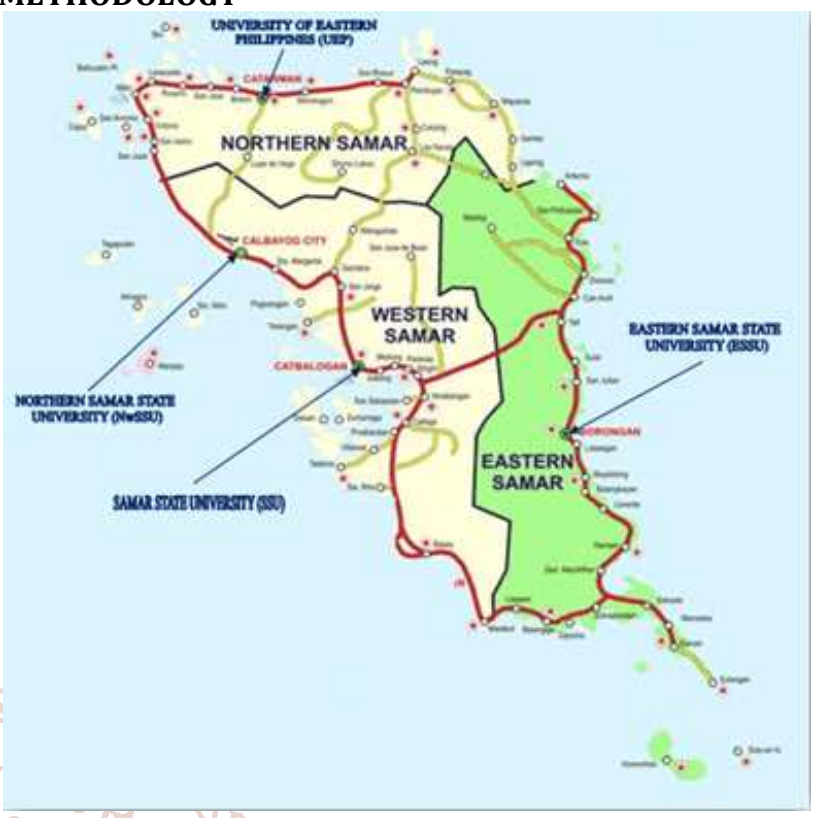

Figure1. Administrative map of Samar Island showing the location of sampled universities

The descriptive-evaluative method of research was utilized in this study. The descriptive data were obtained from the respondents. This study was conducted in state universities that are situated in Samar Island, namely: the University of Eastern Philippines Main Campus (Catarman), North West Samar State University Main Campus (Calbayog City), Samar State University Main Campus (Catbalogan City) and Eastern Samar State University Main Campus (Borongan City). Frequency counts, percentages, and weighted mean computations were used to analyze the descriptive data obtained from the respondents of the study who were chosen through complete enumeration for presidents, deans/directors and personnel and random sampling for the students, respectively.

\section{RESULTS AND DISCUSSION}

The student welfare programs and services include admission, career and placement service, economic enterprise development, food services, guidance and counseling, health services, information and orientation service, international student service, research, monitoring and evaluation of student affairs and services, safety and security, scholarship and financial assistance, services of students with special needs, student discipline, student handbook development, and student housing.

The admission as assessed by the respondents rated very satisfactory. This means that the state universities in the Samar Island were very satisfied on the established system of student recruitment, selection, and admission. This further indicates that the respondents were also very satisfied with the conduct and/or implementation of admission interviews, tests, registration procedure, admission or registration policies and procedures, and filing and management of student handbook. And also on the availability and issuance of scholastic records, documents, 
certification and other pertinent records to students and faculty before and during the enrolment period with adequate staff assisting the student needs.

In terms of career and placement services, it was rated very satisfactory. This means that the respondents were very satisfied with the assistance provided by the Office of Student Affairs in different state universities for vocational and occupational fit and employment of the students. This further indicates that the respondents were very satisfied on the career guidance to enable the students to choose appropriate program/major course and placement services to prospective graduates through linkages to other industries and other prospective employers and be able to maintain a liaison with its alumni for involvement in school affairs. And finally for its follow-up of graduates' performance in government examinations through high percentage of passing licensure examinations, job (entrepreneurship) through successful enterprise, and job (employment) through awards received and key positions in private and government agencies.

Likewise, the economic enterprise development which provides education, guidance, and training to students on the economic enterprise, how it should be managed, and the availability of the different economic enterprise was rated very satisfactory. This means that the respondents were very satisfied with the orientations conducted to explain available economic enterprises for students such as student coop, IGP's, among others, economic empowerment, savings generation, and helping the students with their financial concerns while in school.

The food services as assessed by the respondents had a rate of very satisfactory. This means that the respondents were very satisfied with the insurance of available, safe, and healthful food with promptness and efficient food services through an adequate number of service staff, maintenance of sanitation in the preparation and serving of food.

Moreover, the guidance and counseling revealed that majority of the respondents rated very satisfactory. This means that they were very satisfied on the conduct of orientation activities, placement seminar for graduating students, group guidance and individual counseling, psychological test (mental ability test, personality test, aptitude test, etc.), and career and occupational guidance. Furthermore, they are very satisfied with the proper dissemination of scholarship and information guidelines and guidance services offered, filing and updating of individual records of students, and follow-up services of school achievers and school leader.

In like manner, the health services of the different state universities in Samar Island obtained a rate of very satisfactory, based on assessment of the respondents. This means that the respondents were very satisfied with the services offered by the health units in taking care of the maintenance of health among the school populace as to medical and dental services. This further indicates that they were very satisfied on the provision of medicine to students, medical and dental units are provided with supplies and equipment, availability of full time medical and dental clinic staff, sufficient time for health services to meet the needs of the client, regular and prompt check-up for students, referrals and linkages with other health centers and hospitals, and dissemination of health care information and first aid tips through seminars.

The information and orientation services as assessed by the respondents, had a rate of very satisfactory. This means that the respondents were very satisfied on the orientation conducted regularly at the start of the year and special orientation activities arranged for transferees and returning students, services for the students' adjustment to college life, up-to-date, organized and disseminated information to the students, and available and relevant educational, occupational and social information.

Also, the international student services offered by the different state universities in the Samar Island had a rate of very satisfactory. This means that the respondents were very satisfied with the assistance given by the Office of Student Affairs to the needs of foreign students. This further indicates that the respondents were very satisfied with the services rendered as to educating the university community about the value of international education through cultural programming activities on campus and community resources and issues related to international education, developing social, cultural and educational support services, providing assistance and expertise to the educational community on all questions relative to the situation of international students (customs, special needs, cultural dynamics, etc.), assisting international students/scholars in the transition to living, learning, and working in the domestic setting, providing individual and personal support services for international students in their adjustment to the host country culture, providing informational and educational programs on international student issues/dynamics to all members of the campus community, and identifying and administering financial assistance for international students.

The research, monitoring and evaluation of student affairs and services were rated by the respondents as very satisfactory. This means that the respondents were very satisfied on the feedback mechanism on the effectiveness of the student affairs and services in the different state universities in Samar Island. This further indicates that they were very satisfied on the monitoring the proper dissemination and implementation of student affairs and services to every respective units and colleges, promoting assessment and improvement of higher education services and programs through self-study, evaluation and use of student affairs standards, assessing campus learning, physical environments, learning outcomes, quality of effort and determine program success rates, establishing, adopting, and disseminating unified and timely professional standards for student services, student development programs, academic support services, and related higher education programs and services, evaluating the effectiveness of the services and programs rendered to the students, and establishing demand, need, focus and applicability and to gauge student satisfaction

Moreover, safety and security was also rated very satisfactory. This means that the respondents were very satisfied on the provision of a safe and secure academic environment and that of the members of the academic community in the different state universities in the Island of Samar. This further indicates that they were very satisfied with the hired licensed and competent security officers and staff equipped with knowledge and rightful enforcement of 
school rules and regulations for the preservation and protection of the safety and security of the students and their belongings/property, peace and order, property of the members of the academic community, buildings and facilities of the university, and availability of escorts during off campus activities such as leadership training seminars, educational field trips, etc.

The scholarship and financial assistance, was rated very satisfactory by the respondents. This means that the respondents were very satisfied with the management, generation and/or allocation of funds for scholarship and financial aid to deserving students in the Island of Samar. This further indicates that they were also very satisfied on the implementation of a functional and continuing scholarship program and policies and guidelines in the selection and retention of academic scholars, grantees (dependent children of faculty and staff and barangay officials, indigenous groups, handicapped persons, etc.), members of performing arts, athletes and varsity, etc. Also, on the proper information to the scholars/grantees of their responsibilities concerning grade requirement, duration/time frame of grants or scholarship, and policies and regulations governing the scholarship grants and on the provision of the colleges in providing privileges such as free or discounted school fees, monthly stipend/allowance, book allowance, etc.

The services, programs, and activities designed to provide equal opportunities to students with disabilities, indigenous people, single parents, etc., had a rating of very satisfactory. This further indicates that the respondents were very satisfied on the appropriate assistance and opportunities provided to students with disabilities so that they are able to compete equally with their peers in the academic environment, assistance to students in gaining access to all programs, services and activities sponsored by the university, central point on campus provided to students where facility/program access and other issues can be addressed, and appropriate resources can be secured, provision of the institution to act as the agent to inform the community about access issues, providing leadership in assessing existing and new space/facilities to determine compliance with accessibility criteria and standards set by government units and the institution, assistance to students in acquiring alternative formats of classroom materials (Braille, audio textbooks, large print text), arrangement for appropriate alternative student academic assessment and examination methodologies, and arrangement for notetakers, readers and volunteer books-on-tape readers.

The students' discipline was rated by the respondents as very satisfactory. This means that the respondents were very satisfied with the implementation of institutional rules and regulations governing student behavior in the different state universities in the Island of Samar. This further indicates that they were satisfied in administering the disciplinary process in a manner that respects the due process rights of students while maintaining the integrity of the institution, using the student misconduct to educate students on critical issues such as tolerance, good citizenship, substance abuse, and relationship violence, educating the students on current legal issues related to student conduct, educating students and the community-at-large (including parents) on university rules and regulations, designing the appropriate sanctions to educate students on their behavior risks, complementing the efforts of other units or individuals such as faculty, police and residential life in providing an environment that is conducive to learning by consistently enforcing university policies and regulations, helping the students use mediation and other alternative dispute resolution methods, and resolving any conflict in which a student is involved (student vs. student, faculty vs. student, staff vs. student).

Likewise, the student handbook development program of the different state universities in Samar Island was rated very satisfactory. This means that that the respondents were very satisfied with the availability of the student handbook in electronic and print copies which contains relevant information on academic program offerings, students' rights, information on student welfare and development program and activities, and the involvement of the sections of the academic community in the crafting of the handbook.

The student housing was also rated by the respondents as very satisfactory which means that the respondents were very satisfied with the assistance and information provided by the Office of the Student Affairs in ensuring access to safe, comfortable, well-maintained and supportive housing accommodation for students. This further indicates that they were very satisfied in planning and carrying out study and recreational activities in the residence halls including quiet periods for study, conducting student misconduct disciplinary hearings in cases that originate in student housing, offering a variety of living options including individual, group, alcohol/smoke-free, undergraduate, graduate, disability, first year, and other options, and offering a variety of living options including individual, group, alcohol/smoke-free, undergraduate, graduate, disability, first year, and other options.

All the student welfare programs and services were given very satisfactory ratings by the SUC presidents, deans of Student Affairs, personnel, and students. This means that the respondents from the different state universities in the Island of Samar were very satisfied with the basic services and programs provided by the Office of Student Affairs needed to ensure and promote student well-being.

This confirms with Ludeman's statement that the school administration has the responsibility to provide the best learning environment to students. To make this possible, there is a need for an efficient and effective delivery of student services.

\section{CONCLUSION}

That the status of implementation of the student welfare programs in different state universities in Samar Island was rated very satisfactory. This implies that the services and programs provided by the Office of the Student Affairs ensure and promote the students' well-being which also means that the institution is implementing well its program and services.

The researcher also focused his inquiry on services that are part of student welfare programs but unlikely to be availed of because of the absence or lack, for example, of foreign students for foreign/international student services, of other religious denominations for multi-faith services and of companies offering job opportunities under career and job placement and on new programs like the economic enterprise development. The respondents contended that 
"the institution is ready with the above mentioned services once availed of by the clientele.

Moreover, AACCUP Level 1 accreditation survey results conducted on the state universities surveyed, specifically on Area IV: Support to Students, was photocopied. Results show that based on the 10 areas surveyed by AACCUP accreditors, Area IV, most often than not, logged the highest passing mean rating which is interpreted as that most, if not all of the academic programs' student welfare programs are in place and functional.

\section{References}

[1] Austin, TR., Lau, AR, Wood Brooks, C. (2012). Assessing students' moral and spiritual growth at Catholic Liberal Arts Colleges: A collaborative grant-funded initiative. Journal of College and Character. 13 (4).

[2] Bloland, PA. (2009). Student personnel training for the chief student affairs officer: Essential or unnecessary?. NASPA Journal. 17 (2).

[3] Case, K, Fair, R (2007). Principles of economics. Upper Saddle River, New Jersey: Pearson Education.
[4] Castillon-Boiser, D. (2000). Strategies for teaching: A modular approach. First Edition. Manila: Rex Book Store, Inc.

[5] David, FP. (2005) Understanding and doing research: A handbook for beginners. Iloilo City, Philippines: Panorama Printing, Inc.

[6] Espedido, AB. (2001). The school administrators. The Modern Teacher. 32 (7).

[7] Keitel, R. (2008). A proposed model of higher education institution-Call center industry partnership. The AsiaPacific Education Researcher. 17 (2).

[8] Thurstone, L. L. (2000). The vectors of mind. Chicago: American Psychological Association, Inc.

[9] Torres, V, Jones, SR, Renn, KA. (2009) Identity development theories in student affairs: Origins, current status, and new approaches. Journal of College Student Development. Johns Hopkins University Press. $50(6)$.

[10] Wilson, Everett K. (2001). Sociology: Rules, roles and relationships. Home, Illinois: The Dorsey Press.

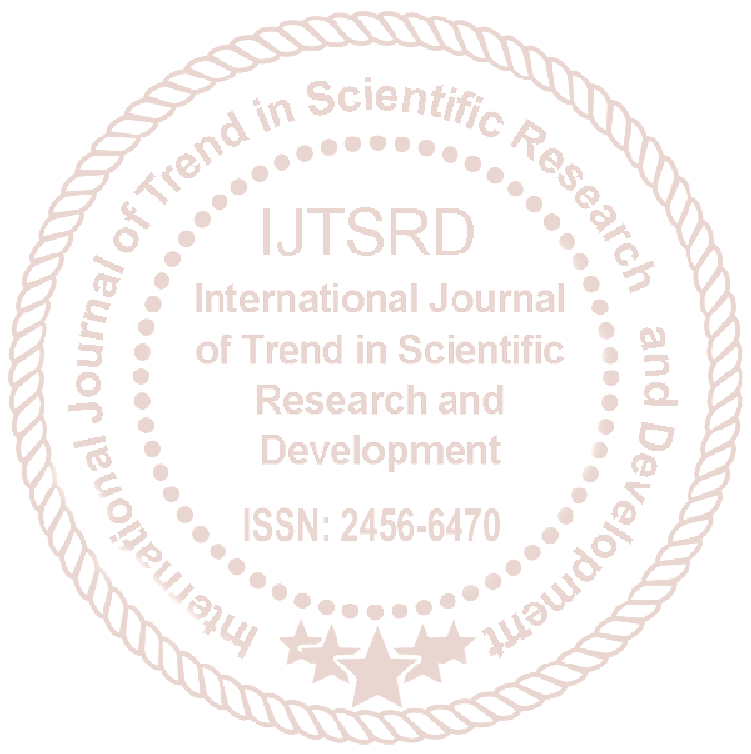

